\title{
CHARACTERIZATION AND ANTIBACTERIAL ACTIVITY OF ZnO NANOPARTICLES SYNTHESIZED BY CO PRECIPITATION METHOD
}

\author{
MANYASREE D. ${ }^{1}$, KIRANMAYI P. ${ }^{2 *}$, VENKATA R KOLLI ${ }^{3}$ \\ ${ }^{1,2 *}$ Department of Biochemistry, Acharya Nagarjuna University, ${ }^{3}$ Department of Toxicology/Global QC (BPANS), Shire Pharmaceuticals, \\ lexington, MA, USA \\ Email: peddikiranmayi@gmail.com
}

Received: 28 Aug 2018, Revised and Accepted: 21 Sep 2018

\section{ABSTRACT}

Objective: In the present study the antibacterial activity of zinc oxide (ZnO) nanoparticles was investigated against gram negative (Escherichia coli and Proteus vulgaris) and gram positive (Staphylococcus aureus and Streptococcus mutans) organisms.

Methods: The synthesis of ZnO nanoparticles was carried out by co-precipitation method using zinc sulfate and sodium hydroxide as precursors. These nanoparticles were characterized by XRD (X-Ray Diffraction), FTIR (Fourier Transform Infrared Radiation), UV-Visible spectroscopy and SEM (Scanning Electron Microscope) with EDX (Energy Dispersive X-ray analysis). As well as antibacterial activity and minimum inhibitory concentration of the nanoparticles were carried out by agar well diffusion method and broth dilution method respectively against gram negative (Escherichia coli and Proteus vulgaris) and gram positive (Staphylococcus aureus and Streptococcus mutans) bacteria.

Results: The average crystallite size of $\mathrm{ZnO}$ nanoparticles was found to be $35 \mathrm{~nm}$ by X-ray diffraction. The vibration bands at 450 and $603 \mathrm{~cm}^{-1}$ which were assigned for ZnO stretching vibration were observed in FTIR spectrum. The optical absorption band at 383 nm was obtained from UVVisible spectrum. Spherical shape morphology was observed in SEM studies. The antibacterial assay clearly expressed that E. coli showed a maximum zone of inhibition ( $32 \pm 0.20 \mathrm{~mm}$ ) followed by Proteus vulgaris $(30 \pm 0.45 \mathrm{~nm})$ at $50 \mathrm{mg} / \mathrm{ml}$ concentration of $\mathrm{ZnO}$ nanoparticles.

Conclusion: Zinc oxide nanoparticles have exhibited good antibacterial activity with gram negative bacteria when compared to gram positive bacteria.

Keywords: ZnO nanoparticles, XRD, FTIR, UV-VISIBLE spectroscopy, SEM, EDX, MIC

(C) 2018 The Authors. Published by Innovare Academic Sciences Pvt Ltd. This is an open access article under the CC BY license (http://creativecommons.org/licenses/by/4.0/) DOI: http://dx.doi.org/10.22159/ijap.2018v10i6.29376

\section{INTRODUCTION}

Development of antibiotic resistant strains has become a serious global problem now a day. One of the promising approaches for overcoming bacterial resistance towards the antibiotics is the use of metallic nanoparticles [1]. Recently, Inorganic antimicrobial agents are used for the control of organisms in various fields [2]. By bringing down the size of bulk material of inorganic metal oxides to nano, it alters their activity and enhances physical, chemical and biological properties [3]. It has been illustrated that highly reactive metal oxide nanoparticles exhibit striking biocidal action against gram positive and gram negative bacteria [4]. Sawai [5] projected that production of hydrogen peroxide be a main factor for the antibacterial function, while Stoimenov [4] elucidated that the binding of $\mathrm{ZnO}$ nanoparticles on the bacterial surface due to electrostatic forces might be a mechanism. The mechanism of action of metal oxide nanoparticles on microorganism alters cell membrane properties, i.e., mainly permeability that facilitates particle penetration inside the microorganism, leading to cellular DNA damage [6]. Generation of reactive oxygen species (ROS) through photocatalysis might be responsible for the biological function of zinc oxide and titanium oxide nanoparticles [7].

The biological activity of the zinc oxide nanoparticles mainly depends on its size, surface area and concentration of the nanoparticle. The antibacterial activity of Zinc oxide nanoparticles along with antibiotics was studied against gram positive (Bacillus subtilis) and gram negative (E. coli) bacteria using disc diffusion method byRavichandrika et al. [8]. Results indicated that zinc oxide nanoparticles enhance the bactericidal activity of macrolides, tetracyclines and beta-lactam antibiotics and similar findings were observed byManyasree and Kiranmayi [9].

Table 1 shows the method and conditions of synthesis plays a key role in determining the size of the nanomaterial. There are few methods such as co-precipitation [10, 11] sol-gel processing [12] micro-emulsions processing, hydrothermal solvo-thermal processing [13], microwave processing, sono-chemical processing and template processing, high temperature solid state reaction, high energy ball milling [14-16] liquid mix process [17], rapid quenching process [18], thermal plasma [19], UV irradiation and lithography are used for synthesizing nanoparticles.

Table 1: Synthesis of nanoparticles by using various methods

\begin{tabular}{|c|c|c|c|}
\hline Method of synthesis & Synthesis conditions & Size of nanomaterial(nm) & Reference \\
\hline Mechanochemical & $300-450{ }^{\circ} \mathrm{C}$ & 51 & {$[20]$} \\
\hline Precipitation & Calcination $2 \mathrm{~h}$ at $600^{\circ} \mathrm{C}$ & 50 & [21] \\
\hline Precipitation in presence of surfactants & Calcination $2 \mathrm{~h}$ at $500{ }^{\circ} \mathrm{C}$ & $54-60$ & [22] \\
\hline Sol-gel method & Calcination at $500^{\circ} \mathrm{C}$, drying $24 \mathrm{~h}$ at $80^{\circ} \mathrm{C}$ & 100 & [23] \\
\hline Microwave techniques & $100-200{ }^{\circ}$ Creaction $5-10 \mathrm{~h}$ & $55-110$ & [24] \\
\hline Micro emulsion & $15 \mathrm{~h}, 140^{\circ} \mathrm{C}$,drying $60^{\circ} \mathrm{C}$ & 45 & [25] \\
\hline
\end{tabular}

In the present research work, an attempt has been made to synthesize the $\mathrm{ZnO}$ nanoparticles by co-precipitation method and investigate the antibacterial activity and minimum inhibitory concentration of $\mathrm{ZnO}$ nanoparticles against gram negative and gram positive bacteria.

\section{MATERIALS AND METHODS}

Zinc sulphate and Sodium hydroxide, involved in the synthesis of $\mathrm{ZnO}$ nanoparticles were purchased from Merck chemicals. The test organisms, E. coli (MCC 2412) and Staphylococcus aureus (MCC- 
2408) were procured from MCC, Pune, India. Proteus vulgaris (MTCC-426) and Streptococcus mutans (MTCC-497) were collected from MTCC, Chandigarh, India. Media required for the cultivation of microorganisms are Nutrient agar (E. coli and Proteus vulgaris)Trypticase soy yeast extract agar (Staphylococcus aureus) and Brain heart infusion agar (Streptococcus mutans) were obtained from Hi-Media Pvt Ltd. All the chemicals used in this experiment were analytical grade and used without further purification.

\section{Synthesis of $\mathrm{ZnO}$ nanoparticles}

The zinc oxide nanoparticles were prepared by co-precipitation method. $1 \mathrm{M}$ of zinc sulfate was dissolved in distilled water and the solution was kept under constant stirring using magnetic stirrer for one hour. After complete dissolution of zinc sulfate, $2 \mathrm{M}$ sodium hydroxide solution was added under constant stirring, drop by drop touching the walls of the vessel. The reaction was allowed to proceed for $2 \mathrm{~h}$. At the end of the reaction, the white creamy solution was formed and was allowed to settle for overnight. The precipitate was washed several times using distilled water then dried at $80^{\circ} \mathrm{C}$. Obtained product was kept at $700{ }^{\circ} \mathrm{C}$ for $3 \mathrm{~h}$ in a muffle furnace. During drying, complete conversion of zinc hydroxide into zinc oxide takes place [26].

\section{Characterization of $\mathrm{ZnO}$ nanoparticles}

The crystal structure of the sample was analyzed by means of XRD6100 diffractometer (Shimadzu), and the patterns were recorded with Copper $\mathrm{K} \alpha$ radiation $\left(\lambda=1.54060 \mathrm{~A}^{\circ}\right)$. Molecular analysis of the samples was performed by Fourier transform infrared (FT-IR) spectroscopy using IR Affinity-1S (Shimadzu) spectrometer, recorded in the wave number range of $400-4,000 \mathrm{~cm}^{-1}$. The maximum optical absorption of the sample was characterized by UVVisible Spectroscopy (JASCO V 670), in the range of 200-800 nm. Morphological study of the nanoparticles was carried out with scanning electron microscope (SEM) (EVO 18 carlzeiss).

\section{Agar well diffusion method}

The antibacterial activity of the nanoparticles was determined by agar well diffusion method [27] against both gram negative and gram positive microorganisms. Once the medium was solidified, a suspension of each sample of the bacteria was diluted prior to $10^{-1}$, $10^{-2}$ and $10^{-3}(1 \mathrm{ml}$ of 108 cells $/ \mathrm{ml})$ and was spread on a solid agar medium in petri plates. The wells were prepared by using sterile cork borer $(6 \mathrm{~mm})$. Each well was filled with different concentrations of nanomaterial ranging from $10-50 \mathrm{mg} / \mathrm{ml}$. The plates were incubated at $37{ }^{\circ} \mathrm{C}$ for $24 \mathrm{~h}$. The zone of inhibition was measured with mean \pm SD values.

\section{Minimum inhibitory concentration}

Broth dilution method [28] was used to determine the minimum inhibitory concentration of $\mathrm{ZnO}$ nanoparticles. A series of 4 test tubes were taken add $10 \mathrm{ml}$ of media and a loop full of culture to all the test tubes and finally add $2 \mathrm{mg} / \mathrm{ml}, 4 \mathrm{mg} / \mathrm{ml}, 6 \mathrm{mg} / \mathrm{ml}$ and 8 $\mathrm{mg} / \mathrm{ml}$ of nanoparticle suspension to each test tube. The test tube without bacterial suspension is considered as control. Keep the test tubes for overnight incubation at $37{ }^{\circ} \mathrm{C}$ temperature. Read the absorbance at $600 \mathrm{~nm}$ using spectrophotometer. MIC is where the absorbance value of sample equals to or near to control [29].

\section{RESULTS AND DISCUSSION}

\section{Co-precipitation method}

The zinc oxide nanoparticles were prepared by co-precipitation method. The synthesis technique is a good choice among all because of simple, direct and rapid procedure [30], homogeneous mixing of reactants [31], easy control of particle size [32], shape and composition of the nanomaterial [33].

\section{Powder X-ray diffraction (XRD) studies}

Powder XRD is a rapid analytical technique primarily used for phase identification of a crystallite material and can provide information on unit cell dimensions. XRD pattern of the synthesized $\mathrm{ZnO}$ nanopowder is in hexagonal phase. The sharper and stronger diffraction peaks were observed from fig.1. The diffraction peaks at $31.75^{\circ}, 34.40^{\circ}, 36.23^{\circ}$, $47.53^{\circ}, 56.59^{\circ}, 62.85^{\circ}, 66.39^{\circ}, 67.94^{\circ}$ and $69.07^{\circ} 2 \theta$ which are associated with (100), (002), (101), (102), (110), (103), (200), (112) and (201) planes, respectively and were indicated in table 2 . The (hkl) values are well agreed with the standard cards of $\mathrm{ZnO}$ (JCPDS file No: 79-2205). The average crystallite size of the sample (D) is calculated using Debye Scherrer's formula:

$$
\mathrm{D}=0.9 \lambda / \beta \cos \theta
$$

Where, $\lambda$ is the wavelength of the X-ray radiation, $\theta$ is the diffraction angle and $\beta$ is the full width half maximum (FWHM) intensity. On substituting the values $\lambda=1.5408, \beta=0.041, \cos \theta=0.9504$ in Debye Scherrer's formula $(0.9 \times 1.5408) \div(0.041 \times 0.9504)=35 \mathrm{~nm}$. The prominent peaks were used to estimate the grain size of sample with the help of Scherrer's equation and it can be indexed to the hexagonal crystal structure. The calculated average crystallite size is found to be $35 \mathrm{~nm}$. Crystallite size of the nanoparticles was determined from the line broadening of X-ray diffraction peak by using above mentioned formula. The evaluated cell parameters $a=0.32511$ and $c=0.52069 \mathrm{~nm}$ are in close agreement with the reported values.

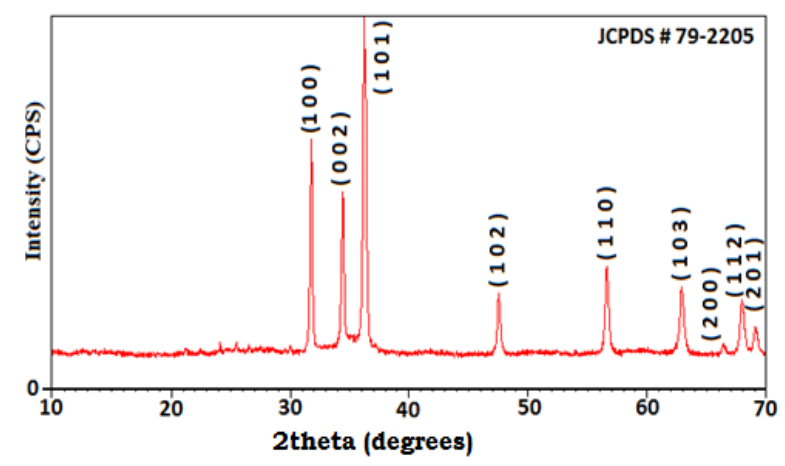

Fig. 1: XRD patterns of the zinc oxide nanoparticles

Table 2: The observed and standard $2 \theta$ values of XRD data of zinc oxide nanoparticles

\begin{tabular}{|c|c|c|}
\hline Observed $2 \theta$ & Standard $2 \theta$ & h k l \\
\hline 31.75 & 31.76 & 100 \\
\hline 34.40 & 34.41 & 002 \\
\hline 36.23 & 36.25 & 101 \\
\hline 47.53 & 47.53 & 102 \\
\hline 56.59 & 56.59 & 110 \\
\hline 62.85 & 62.85 & 103 \\
\hline 66.39 & 66.37 & 200 \\
\hline 67.94 & 67.94 & 112 \\
\hline 69.07 & 69.08 & 201 \\
\hline
\end{tabular}

\section{Fourier transform infrared spectroscopy (FTIR) analysis}

Synthesized zinc oxide nanoparticles were subjected to FTIR spectral study to identify various functional groups related to the prepared nanoparticle. FTIR spectrum of synthesized zinc oxide nanoparticles was shown in fig. 2. The Peaks at 450 [34] and 603 are assigned to the $\mathrm{Zn}-\mathrm{O}$ stretching vibration [8]. The peak at 1121 indicates the triply degenerative vibrational mode of sulphate ion. 
The peaks at 1638 and 3405 are assigned to the bending and stretching vibration mode of water molecule.

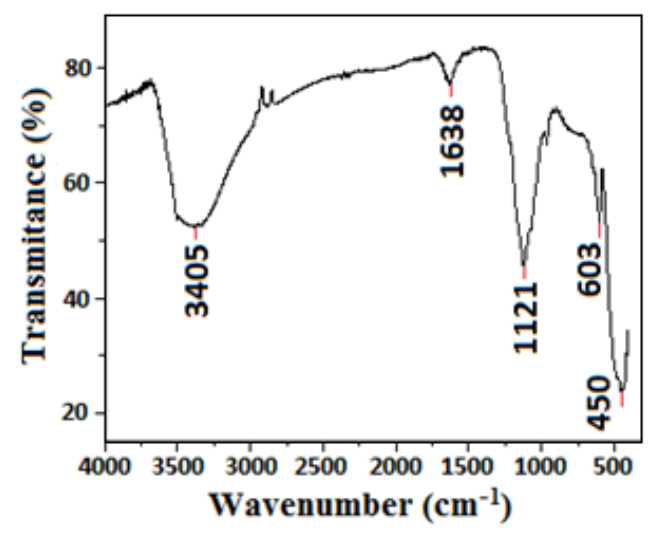

Fig. 2: FT-IR spectrum of zinc oxide nanoparticles

\section{UV-Visible spectroscopy studies}

UV-Visible spectroscopy is most widely used technique to investigate the optical properties of the particles. UV-Visible spectroscopy analysis was done in the range of 200-800 $\mathrm{nm}$. Zinc oxide nanoparticles typically exhibit optical absorption around 370 $\mathrm{nm}$ [35-36]. The optical absorbance spectra of zinc oxide nanopowder showed in fig. 3 . The band was observed at $383 \mathrm{~nm}$ assigned to the absorption of zinc oxide nanoparticles.

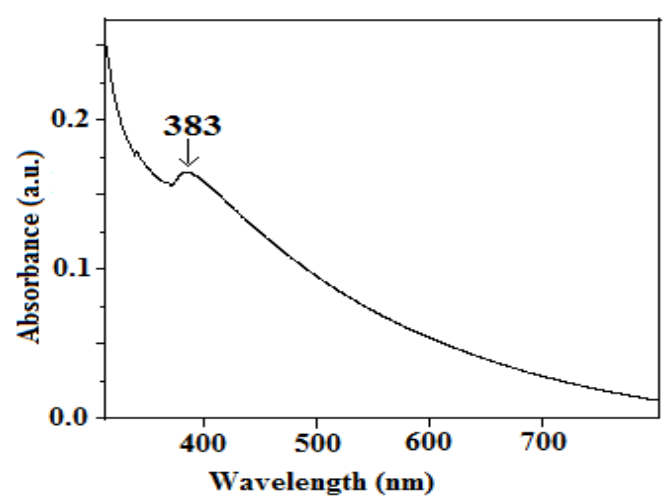

Fig. 3: Optical absorption spectrum of zinc oxide nanoparticles

\section{Scanning electron microscope and EDX analysis}

Fig. 4 represents the SEM images of zinc oxide nanopowder at different magnifications. Surface morphology of zinc oxide nanopowder was deduced by using scanning electron microscopy (SEM). The results revealed that particles in the sample were compactly arranged and shown spherical morphology [37]. The appearance of larger nanoparticles is due to van der Waals clusters of smaller entities and magnetic interactions among the particles. The purity of the product was further confirmed by EDX analysis. In fig.5 EDX elucidates the surface atomic distribution and chemical composition of nanoparticles. The quantitative analysis of EDX spectrum reflects the presence of $\mathrm{Zn}$ and 0 peaks clearly indicated that the product was of pure $\mathrm{ZnO}$ devoid of impurities. The other weaker signals of $\mathrm{K}, \mathrm{L}$ and $\mathrm{S}$ are owing to use precursor salts for the synthesis of nanoparticles.

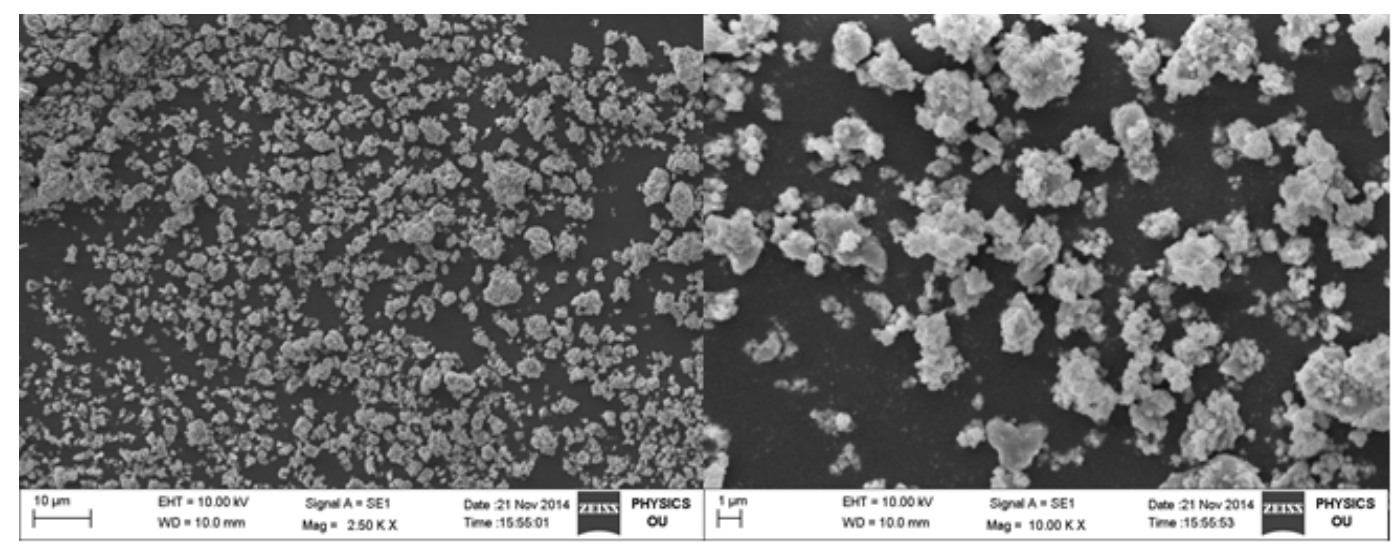

Fig. 4: SEM analysis of zinc oxide nanoparticles

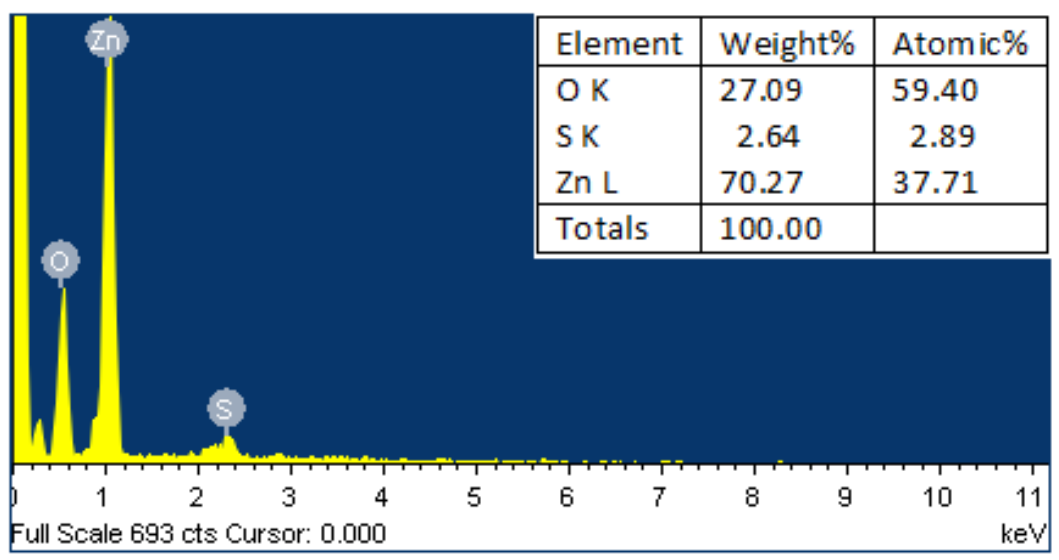

Fig. 5: EDX spectrum of zinc oxide nanoparticles 


\section{Antibacterial activity of the zinc oxide nanoparticles}

The antibacterial activity of zinc oxide nanoparticles was tested against gram negative bacteria E. col i(MCC-2412), P. vulgaris (MTCC-426) and gram positive bacteria $S$. aureus (MCC-2408) and $S$. mutans (MTCC-497) by agar well diffusion method. In fig.6 antibacterial activities of zinc oxide nano particles at different concentrations $10 \mathrm{mg} / \mathrm{ml}, 20 \mathrm{mg} / \mathrm{ml}, 30 \mathrm{mg} / \mathrm{ml}, 40 \mathrm{mg} / \mathrm{ml}, 50$ $\mathrm{mg} / \mathrm{ml}$ against both gram negative and gram positive bacteria were shown. The diameter of inhibition zones around each well is measured in millimeters and represented in table 3. Similar results were published by Rizwan et al., 2010 [38]. Results have indicating that the degree of zone of inhibition (with mean $\pm S D$ values) was more against gram negative bacterial strains E. coli $(32 \pm 0.20 \mathrm{~mm})$ and Proteus vulgaris $(30 \pm 0.45 \mathrm{~mm})$ when compared to the gram positive bacteria (Staphylococcus aureuswith $24 \pm 0.35 \mathrm{~mm}$ and Streptococcus mutanswith $23 \pm 0.30 \mathrm{~mm}$ ). The formation of an inhibition zone evidently states the mechanism of the biocidal action of nanoparticles involves disrupting the membrane. Range of inhibition depends on the concentration of nanoparticles as well as on the initial bacterial concentration. Due to the smaller size of the nanoparticles they can easily pass through the membrane and can destruct the cell. The important feature of the nanoparticles is large surface area, so that they can tightly bind to the surface of the bacterial cells to disrupt the membrane which would lead to the leakage of intracellular components and that kills the bacterial cells. Nanotoxicity may be attributed to electrostatic interaction between nanoparticles with bacterial cell membrane. Generation of reactive oxygen species (ROS) like hydroxyl ions, peroxides, super oxides and hydrogen peroxide may be the main reason for nanotoxicity of zinc oxide nanoparticles. The lethal agent hydrogen peroxide which is actually produced from hydroxyl ions and peroxide free radicle could damage the cell by complete destruction of membrane of bacterial cells [39]. As well as differences in structural organization between both gram classes of bacterial cell wall i.e. due to the presence of thicker peptidoglycan layer in gram positive bacteria, they are less prone to nanotoxicity of $\mathrm{ZnO}$ nanoparticles when compared to gram negative bacteria. This is might be the reason for the obtained results that indicates high degree of inhibition zone in the case of gram negative bacteria compared to gram positive bacteria.

Table 3: Antibacterial activity of $\mathrm{ZnO}$ nanoparticles by agar well diffusion method

\begin{tabular}{|c|c|c|c|c|c|}
\hline \multirow[t]{2}{*}{ Organism } & \multicolumn{5}{|c|}{ Zone of inhibition (mm) } \\
\hline & $10 \mathrm{mg} / \mathrm{ml}$ & $20 \mathrm{mg} / \mathrm{ml}$ & $30 \mathrm{mg} / \mathrm{ml}$ & $40 \mathrm{mg} / \mathrm{ml}$ & $50 \mathrm{mg} / \mathrm{ml}$ \\
\hline E. coli & $7 \pm 0.25$ & $14 \pm 0.30$ & $21 \pm 0.25$ & $28 \pm 0.30$ & $32 \pm 0.20$ \\
\hline P. vulgaris & $6 \pm 0.25$ & $12 \pm 0.35$ & $18 \pm 0.45$ & $24 \pm 0.25$ & $30 \pm 0.45$ \\
\hline S. aureus & $6 \pm 0.35$ & $10 \pm 0.15$ & $14 \pm 0.10$ & $19 \pm 0.15$ & $24 \pm 0.35$ \\
\hline S. mutans & $4 \pm 0.25$ & $9 \pm 0.35$ & $13 \pm 0.35$ & $18 \pm 0.35$ & $23 \pm 0.30$ \\
\hline
\end{tabular}

Number of experiments $n=2$, mean $\pm S D$

\section{Minimum inhibitory concentration}

In broth medium, MIC is where the absorbance value of sample equals to or near to control [29]. In solid medium, lowest concentration of nanoparticle suspension at which the bacterial colonies appeared on the top of the fresh medium in petri dishes is the MIC [40]. Minimum inhibitory concentration (MIC) of the zinc oxide nanopowder was determined by using broth dilution method. MIC was determined at different concentrations like $2 \mathrm{mg} / \mathrm{ml}, 4$ $\mathrm{mg} / \mathrm{ml}, 6 \mathrm{mg} / \mathrm{ml}$ and $8 \mathrm{mg} / \mathrm{ml}$ and control against two gram positive and two gram negative organisms.

The results showed significant MIC values between $2 \mathrm{mg} / \mathrm{ml}$ to 8 $\mathrm{mg} / \mathrm{ml}$ concentration. E. coli and Proteus vulgaris showed MIC at 6 $\mathrm{mg} / \mathrm{ml}$, streptococcusmutans showed MIC at $8 \mathrm{mg} / \mathrm{ml}$ and staphylococcusaureus showed MIC at $4 \mathrm{mg} / \mathrm{ml}$ for zinc oxide nanopowder in table 4.

Table 4: Minimum inhibitory concentration (MIC) values in $(\mathrm{mg} / \mathrm{ml})$ of ZnOnano powder

\begin{tabular}{ll}
\hline Bacterual strain & MIC(mg/ml) \\
\hline E. coli & 6 \\
P. vulgaris & 6 \\
S. aureus & 4 \\
S. mutans & 8 \\
\hline
\end{tabular}

\section{CONCLUSION}

Based on the results, it can be concluded that gram negative organisms have exhibited more sensitivity when compared to gram positive organisms to metal oxide nanoparticles [41]. The difference in the activity of both gram negative and gram positive bacteria might be due to structural and compositional variations of the cell membrane [42, 43, 44]. Gram positive bacteria have thicker peptidoglycan layer when compared to gram negative bacteria due to this kind of difference in structure, it is tough for nanoparticles to penetrate into membrane resulting in a low bacterial action [45]. All microbial species and strains are not exhibiting the same sensitivity to metal oxide nanoparticles [27]. The concentration of the nanoparticle plays a significant role in the resolution of antibacterial activity. The surface area of the metal oxide nanoparticles that comes in contact with bacterial cells is directly proportional to the extent of antimicrobial activity recommended by the particle.

\section{AUTHORS CONTRIBUTIONS}

All the author have contributed equally

\section{CONFLICT OF INTERESTS}

Declared none

\section{REFERENCES}

1. Choi O, Yu CP, Esteban Fernández G, Hu Z. Interactions of nanosilver with escherichia coli cells in planktonic and biofilm cultures. Water Res 2010;44:6095-103.

2. Wilczynski M. Antimicrobial porcelain enamels. Cerr Eng Sci Proceedings 2000;21:81-3.

3. Nicole J, Binata R, Koodali T, Ranjit C. Antibacterial activity of ZnO nanoparticle suspensions on a broad spectrum of microorganisms. FEMS Microbiol Lett 2008;279:71-6.

4. Stoimenov PK, Klinger RL, Marchin GL, Klabunde KJ. Metal oxide nanoparticles as bactericidal agents. Langmuir 2002;18:6679-86.

5. Sawai J, Kawada E, Kanou F, Igarashi H, Hashimoto A, Kokugan T, et al. Detection of active oxygen generated from ceramic powders having antibacterial activity. J Chem Eng Japan 1996;29:627-33.

6. Brigger I, Dubernet C, Couvreur P. Nanoparticles in cancer therapy and diagnosis. Adv Drug Delivery Rev 2002;54:631-51.

7. Jia You, Yanyan Zhang, Zhiqiang Hu. Bacteria and bacteriaophage inactivation by silver and zinc oxide nanoparticles. Colloids Surf B 2011;85:161-7.

8. Ravichandrika K, Kiranmayi P, Ravi Kumar RVSSN. Synthesis, characterization and antibacterial activity of $\mathrm{ZnO}$ nanoparticles. Int J Pharm Pharm Sci 2012;4:336-8. 
9. Manyasree D, Kiranmayi P. ZnO nanoparticles: role in enhancing antibacterial activity of various antibiotics against Escherichia coli. Indo Am J Pharm Res 2017;9:399-402.

10. Kundu A, Anand S, Verma HCA. Citrate process to synthesize nanocrystalline zinc ferrite from 7 to $23 \mathrm{~nm}$ crystallite size. Powder Technol 2003a;132:131-6.

11. Raeisi Shahraki R, Ebrahimi M. Synthesize of superparamagnetic zinc ferrite nanoparticles at room temperature. J Neurosurg 2013;2:413-6.

12. Hamdeh HH, Ho JC, Oliver SA, Willey RJJ, Oliveri G, Busca G. Magnetic properties of partially-inverted zinc ferrite aerogel powders. J Appl Phys 1997;81:1851-8.

13. Toledo-Antonio JA, Nava N, Martinez M, Bokhimi X. Correlation between the magnetism of non-stoichiometric zinc ferrites and their catalytic activity for oxidative dehydrogenation of 1butene. Appl Catal A 2002;234:137-44.

14. Bid S, Pradhan SK. Preparation of zinc ferrite by high energy ball-milling and microstructure characterization by rietveld's analysis. Mater Chem Phys 2003;82:27-37.

15. Ehrhardt H, Campbel SJ, Hofmann M. Magnetism of the nanostructured spinel zinc ferrite. Scr Mater 2003;48:1141-6.

16. Shenoya SD, Joy PA, Anantharaman MR. Effect of mechanical milling on the structural, magnetic and dielectric properties of co-precipitated ultrafine zinc ferrite. J Magn Magn Mater 2004;269:217-26

17. Kundu A, Upadhyay C, Verma HC. Magnetic properties of a partially inverted zinc ferrite synthesized by a new coprecipitation technique using urea. Phys Lett 2003b;311:410-5.

18. Tanaka K, Makita M, Shimizugawa Y, Hirao K, Soga N. Structure and high magnetization of rapidly quenched zinc ferrite. J Phys Chem Solids 1998;59:1611-8.

19. Mohair I, Szepvolgyi J, Bertoti I, Mohai M, Gubicaz J, Ungar T. Thermal plasma synthesis of zinc ferrite nanopowders. Solid State Ion 2001;163:141-2.

20. Aghababazadeh R, Mazinani B, Mirhabibi A, Tamizifar M. ZnO nanoparticles by mechanochemical processing. J Phys Chem Solids 2006;26:312-4.

21. Xu J, Pan Q, Shun Y, Tian Z. Grain size control and gas sensing properties of $\mathrm{ZnO}$ gas sensor. Sens Actuator B-Chem 2000;66:277-9.

22. Wang Y, Ma C, Sun X, Li H. Preparation of nanocrystalline metal oxide powders with the surfactant-mediated method. Inorg Chem Commun 2002;5:751-5.

23. Mahato TH, Prasad GK, Acharya BSJ, Srivastava AR, Vijayaraghavan R. Nanocrystalline zinc oxide for the decontamination of sarin. J Hazard Mater 2009;165:928-32.

24. Ismail AA, El-Midany A, Abdel-Aal EA, El-Shall H. Application of statistical design to optimize the preparation of $\mathrm{ZnO}$ nanoparticles via hydrothermal technique. Mater Lett 2005; 59:1924-8.

25. Li X, He G, Xiao G, Liu H, Wang M. Synthesis and morphology control of $\mathrm{ZnO}$ nanostructures in microemulsions. J Colloid Interface Sci 2009;333:465-73.

26. Zhang H, Yang D, Ma X, Ji Y, Xu J, Que D. Synthesis of flower-like $\mathrm{ZnO}$ nanostructures by an organic-free hydrothermal process. Nanotechnology 2004;15:622-6.

27. Geoprincy G, Nagendhra Gandhi N, Renganathan S. Novel antibacterial effects of alumina nanoparticles on bacillus cereus and bacillus subtilis in comparison with antibiotics. Int J Pharm Pharm Sci 2012;4:544-8.
28. Umamaheswara Rao V, Nagababu P. Pharmacological evaluation of ceriopsdecandra (Griff.) dinghou stem extracts. Int J Rec Sci Res 2015;6:2783-9.

29. Ruparelia JP, Arup Kumar Chatterjee, Siddhartha P, Duttagupta, Suparna Mukherji. Strain specificity in antimicrobial activity of silver and copper nanoparticles. Acta Biomater 2008;4:707-16.

30. Wang F, Liu X. In: Comprehensive nanoscience and technology. eds. Editors-in-Chief: David L. Andrews, Gregory D Scholes, Gary P. Wiederrecht, Academic Press: Amsterdam; 2011. p. 607-35.

31. Juliana Cristina de Freitas, Rogeriomendesbranco. Magnetic nanoparticles obtained by homogeneous coprecipitation sonochemically assisted. Mat Res 2015;18:220-4.

32. Madankumar M, Sivakumar D, Premkumar S, Manivannan M, Mohamed Rafi M, Prem Nazeer, et al. Synthesis and dielectric studies of magnetite nanoparticles. J Emer Tech Inn Res 2018;5:886-97.

33. Qiao SZ, Liu J, Lu GQ. Synthetic chemistry of nanomaterials. $2^{\text {nd }}$ edition. Modern Inorganic Synthetic Chemistry; 2017.

34. Gnanasangeetha D, Sarala Thambavani. One pot synthesis of zinc oxide nanoparticles via chemical and green method. Res J Material Sci 2013;1:1-8.

35. Divya MJ, Sowmia C, Joona K, Dhanya KP. Synthesis of zinc oxide nanoparticle from Hibiscus rosa-sinensisleaf extract and investigation of its antimicrobial activity. Res J Pharm Biol Chem Sci 2013;4:1137-42.

36. Prabhu YT, Siva Kumari B, Venkateswara Rao K, Kavitha V, Aruna Padmavathi D. Surfactant assisted synthesis of $\mathrm{ZnO}$ nanoparticles, characterization and its antimicrobial activity against staphylococcus aureus and escherichia coli. Int J Cur Eng Tech 2014;4:1038-41.

37. Haritha Meruvu, Meena Vangalapati, Seema Chaitanya Chippada, Srinivasa Rao Bammidi. Synthesis and characterization of zinc oxide nanoparticles and its antimicrobial activity against bacillus subtilis and escherichia coli. Rasayan J Chem 2011;1:217-22.

38. Rizwan W, Nagendra KK, Akhilesh KV, Anurag M, Hwang $\mathrm{IH}_{\text {, }}$ You-Bing Y, et al. Fabrication and growth mechanism of $\mathrm{ZnO}$ nanostructures and their cytotoxic effect on human brain tumor U87, cervical cancer HeLa, and normal HEK cells. J BiolInorg Chem 2010;16:431-42.

39. Halliwell B, Gutteridge JMC. Oxygen toxicity, oxygen radicals, transition metals and disease. Biochem J 1984;219:1-14.

40. Emami Karvani Z, Pegah Chehrazi. Antibacterial activity of $\mathrm{ZnO}$ nanoparticle on gram positive and gram negative bacteria. Microbiol Res 2011;5:1368-73.

41. Vellora V, Padil T, Cernik M. Green synthesis of copper oxide nanoparticles using gum karaya as a biotemplate and their antibacterial application. Int J Nanomed 2013;8:889-98.

42. Heinlaan M, Ivask A, Blinova I, Dubourguier HC, Kakru A. Toxicity of nanosized and bulk $\mathrm{ZnO}, \mathrm{CuO}$ and $\mathrm{TiO}_{2}$ to bacteria Vibrio fischeriand crustaceans daphnia magna and thamnocephalusplatyurus. Chemosphere 2008;71:1308-16.

43. Manyasree D, Kiranmayi P, Ravikumar R. CuO nanoparticles: synthesis, characterization and their bactericidal efficacy. Int J Appl Pharm 2017;6:71-4.

44. Manyasree D, Kiranmayi P, Ravikumar RVSSN. Synthesis, characterization and antibacterial activity of aluminium oxide nanoparticles. Int J Pharm Pharm Sci 2018;1:32-35.45.

45. Awale JS, Dey K, Pasricha R, Sood KN, Srivastava AK. Synthesis and characterization of ZnOtetrapods for optical and antibacterial applications. Thin Solid Films 2010;519:1244-7. 